Article

\title{
The Geochemistry of 1 ky Old Euxinic Sediments of the Western Black Sea
}

\author{
Octavian G. Duliu ${ }^{1,2, *,+} \oplus$, Carmen I. Cristache ${ }^{3,+}{ }^{,}$Ana-Voica Bojar ${ }^{4,5,+}+\mathbb{C}$, Gheorghe Oaie ${ }^{6,+}$,

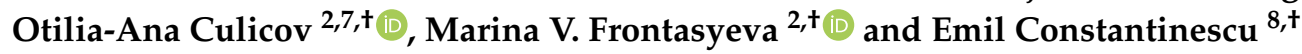 \\ 1 Department of the Structer of Matter, Earth and Atmospheric Physics and Astrophysics, \\ University of Bucharest, P.O. Box MG-11, 077125 Magurele (Ilfov), Romania \\ 2 Joint Institute for Nuclear Research, Joliot Curie str. 6, 141980 Dubna, Russia; culicov@nf.jinr.ru (O.-A.C.); \\ marina@nf.jinr.ru (M.V.F.) \\ 3 National Institute of Research and Development for Physics and Nuclear Engineering "Horia - Hulubei", \\ P.O. Box MG-6, 077125 Magurele (Ilfov), Romania; carmen.cristache9@gmail.com \\ 4 Geographie und Geologie, Salzburg University, Kapitelgasse 4-6, 5020 Salzburg, Austria; \\ Ana-Voica.Bojar@sbg.ac.at \\ 5 Studienzentrum Naturkunde, Universalmuseum Joanneum, Weinzöttlstraße 16, 8045 Graz, Austria \\ 6 National Institute of Marine Geology and Geoecology, Dimitrie Onciul str. 23-25, 024053 Bucharest, \\ Romania; astanica@geoecomar.ro \\ 7 National Institute for Research and Development in Electrical Engineering, 313 Splaiul Unirii, 060032 \\ Bucharest, Romania \\ 8 Department of Mineralogy, University of Bucharest, Nicolae Balcescu Blv. 1, 010041 Bucharest, Romania; \\ emil@constantinescu.ro \\ * Correspondence: o.duliu@upcmail.ro \\ + These authors contributed equally to this work.
}

Received: 18 July 2019; Accepted: 18 October 2019; Published: date

check for updates

\begin{abstract}
To get more data on the geochemistry of Black Sea euxinic sediments, a 50-cm core was collected at a depth of $600 \mathrm{~m}$ on a Western Black Sea Continental Platform slope. The core contained unconsolidated sediments rich in cocoolithic ooze and mud. Epithermal Neutron and Prompt Gamma Activation Analysis were used to determine the content of nine major ( $\mathrm{Na}, \mathrm{Mg}, \mathrm{Al}, \mathrm{Si}, \mathrm{K}, \mathrm{Ca}, \mathrm{Ti}, \mathrm{Mn}$, and Fe as oxides) and 32 trace elements (Cl, Sc, V, Cr, Co, Ni, Zn, As, Se, Br, Rb, Sr, Zr, Mo, Sn, Sb, Cs, $\mathrm{Ba}, \mathrm{La}, \mathrm{Ce}, \mathrm{Nd}, \mathrm{Sm}, \mathrm{Eu}, \mathrm{Gd}, \mathrm{Tb}, \mathrm{Dy}, \mathrm{Yb}, \mathrm{Hf}, \mathrm{Ta}, \mathrm{W}, \mathrm{Th}$, and $\mathrm{U}$ ) with a precision varying between 3 and 9\%. The core contained unconsolidated sediment rich in coccolithic ooze and mud. Previous ${ }^{210} \mathrm{~Pb}$ geochronology suggests an age of $\sim 1 \mathrm{ky}$ of considered sediments. Major components distribution showed that, except for $\mathrm{Cl}$ and $\mathrm{Ca}$, the contents of all other elements are similar to Upper Continental Crust (UCC) and North American Shale Composite (NASC). The distribution of the 32 trace elements showed similarities to the UCC, except for redox-sensitive metals Fe, Se, Mo, and U, of which the significantly higher content reflects the presence of euxinic conditions during deposition. A chondrite normalized plot of nine rare earth elements indicated a similarity to UCC and NASC, suggesting a continental origin of sedimentary material.
\end{abstract}

Keywords: Black Sea; geochemistry; unconsolidated sediments; euxinic zone; redox-sensitive elements

\section{Introduction}

The Black Sea, an inland sea with a surface area of $422,000 \mathrm{~km}^{2}$ and a maximum depth of $2212 \mathrm{~m} \mathrm{[1]}$, is also the largest meromictic basin in the world. About $7 \mathrm{ky}$ ago, after a massive influx of the Mediterranean seawater through the Bosporus strait, the Black Sea stratified into two unmixed layers: a surface layer, well-oxygenated one with a thickness varying between 120 and $180 \mathrm{~m}$, and 
a much thicker layer below the oxygenated one, filling the rest of the basin. The lower layer, devoid of oxygen and saturated with hydrogen sulfide, forms an euxinic environment, populated only by extremophile bacteria that produce hydrogen sulfide and carbon dioxide [2,3].

As the euxinc zone is completely devoid of bioturbating organisms, it represents an ideal environment to preserve sedimentary structure for long periods of time, thus allowing a systematic reconstruction of past processes.

The Black Sea catchment basin extends over Europe and the Anatolian Peninsula and covers an area of 1,874,904 $\mathrm{km}^{2}$. The main tributaries-Danube, Dniester, Bug, and Dnepr-with a combined inflow of $261 \mathrm{~km}^{3} / \mathrm{y}$, represent $76 \%$ of the entire tributary discharge into the Black Sea [4]. The Danube itself contributes annually with about 3.0-3.5 $\times 10^{7}$ tons of sediments, which are discharged and spread over the western continental platform $[5,6]$ as well as within the euxinic zone.

We present and discuss our experimental results concerning the elemental composition of the unconsolidated marine sediments collected from the euxinic zone of the Black Sea. Detailed vertical profiles of of redox-sensitive metals, such as $\mathrm{Fe}, \mathrm{Se}, \mathrm{Mo}$, or $\mathrm{U}$ are useful for the reconstruction of past environmental events [5-13], while the distribution of other elements such as Sc, Zr, REE(rare earth elements), $\mathrm{Ni}$, and Th can provide relevant information concerning the source of sedimentary material [14-17].

In order to assess the past geochemical evolution as reflected in a 50-cm-long core, of which estimated age was about $1 \mathrm{ky} \mathrm{[18],} \mathrm{and} \mathrm{to} \mathrm{increase} \mathrm{the} \mathrm{accuracy} \mathrm{of} \mathrm{measurements,} \mathrm{we} \mathrm{have} \mathrm{used} \mathrm{two}$ complementary analytical techniques: Epithermal Neutron Activation Analysis (ENAA) and Prompt Gamma-ray Activation Analysis (PGAA).

As the main objects of this study aim to obtain additional data concerning the possible evolution of the euxinic environment in the past $1 \mathrm{ky}$ as well as the origin of sedimentary material, we have focussed our analysis on the most important elements for this study, i.e., Fe and redox-sensitive elements Se, Mo, and $\mathrm{U}$ as well as $\mathrm{Sc}, \mathrm{Ni}, \mathrm{Zr}$, eight $\mathrm{REE}$, and $\mathrm{Th}$.

\section{Materials and Methods}

\subsection{Samples}

A 50-cm-long core, (code number BS 600) was collected at a water depth of $600 \mathrm{~m}$ using a Mark II-400-type multicorer during a June 2004 scientific cruise of the National Institute of Marine Geology and Geoecology R/V Mare Nigrum [19]. The collecting point was located eastward of Constanta (Romania) (Figure 1, inset). After collection, the 12-cm diameter BS 600 core was sealed and stored in vertical position in a refrigerator for about a week. Then, after the end of cruise, the core was examined by means of a Siemens Somatom HQ Computer Tomograph, which showed an alternation of about 254 horizontal-millimetres thick and almost parallel laminae of coccolithic and argilaceous mud, undisturbed by biotic activity (Figure 1a,b).

A few weeks later, the core was longitudinally split into two halves, with one of them being divided into 45 segments, $5 \mathrm{~mm}$ to $5 \mathrm{~cm}$ thick, for further investigations [20]. Each segment was then dehydrated at $105^{\circ} \mathrm{C}$, homogenized, and divided into four aliquots, with two of them of about $1 \mathrm{~g}$ for ENAA and PGAA, one of them of 15 to $100 \mathrm{~g}$ for radiometric, and one of them of about $10 \mathrm{~g}$ for additional mineralogical analysis and Total Organic Carbon (TOC) determination.

\subsection{Analytical Techniques}

Instrumental Neutron Activation Analysis (INAA) still represents one of the best analytical methods to determine the concentration of 38 to 40 elements existing in nature in a range of concentrations up to $100 \mathrm{ng} / \mathrm{kg}$ without laborious radiochemical separations or acid digestion [21,22].

ENAA was performed at the IBR-2 pulsed fast reactor of the Joint Institute for Nuclear Research (JINR), Dubna (Russian Federation), and PGAA was performed at the Budapest Research Reactor, Hungary. Certified reference materials IAEA-SL-3 lake sediment and IAEA SL-7 soil were used for 
calibration, while IAEA SL-1 lake sediment was used to check the accuracy of measurements. All certified reference materials were irradiated together with the investigated samples under the same conditions. Except $\mathrm{Na}$, the content of all elements as determined by both methods were coincident at $p<0.05$. For all elements, the precision in determining their concentrations was better than $9 \%$ (Table A1).

In the case of ENAA, the neutron energies varied between thermal $0.025 \mathrm{eV}$ and resonant $500 \mathrm{eV}$ which significantly increases both sensitivity and accuracy of measurement [23]. The PGAA, which is based on the analysis of the gamma rays emitted during neuron capture by nuclei, allows determining with high accuracy the content of some elements such as Gd for which classic INAA gives great errors. More details concerning ENAA and PGAA determinations can be found in References [24-26].

The mineralogical analysis of major components was performed by X-ray diffraction (XRD) using a $\mathrm{Cu}$ anode DRON-3 diffractometer provided with a graphite monochromator and a $\mathrm{NaI}(\mathrm{Tl})$ detector, while the presence of trace minerals was investigated by microscopy using a binocular microscope. The XRD spectra were interpreted by means of the Crystallography Open Database [27] .

Finally, TOC was determined using a LECO RC-412 Carbon Analyzer (Leco.inc., Saint Joseph, MI, USA) with an accuracy of about $10 \%$.

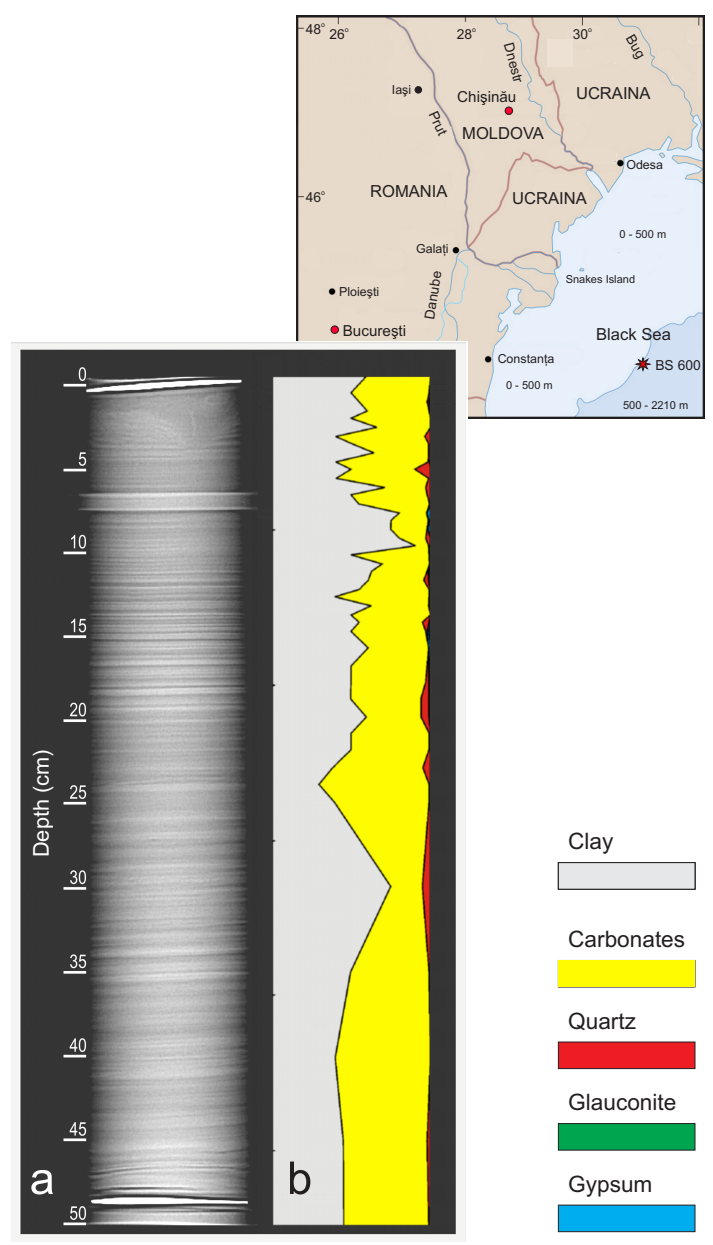

Figure 1. A tomographic image of the BS 600 core (a) and the vertical distribution of the main mineral fractions (in \%) (b): The inset illustrates the position of the BS 600 collecting point location on the slope of the Western Black Sea continental platform.

\section{Results}

The vertical distribution of the main minerals, as resulted by X-ray diffraction determination, is illustrated in Figure 1b, while the corresponding numerical values of their concentrations are provided 
in Table A2. A careful examination of both Figure $1 \mathrm{~b}$ and Table A2 showed that the clay and carbonate, the main mineral fractions, account for about $98 \%$ while quartz, gypsum, and glauconite are the minor ones. It should also be noted that, in the upper portion of the core, carbonate decreases while quartz was more abundant (Figure 1b). Traces of other minerals such as titanite, rutile, and zircon as well as microorganism tests (mainly Emiliania huxlei cocoolithes) were identified under binocular microscopy. The TOC content varied between $3 \%$ and $6 \%$, in good concordance with previous data reported in Reference [28].

The final experimental data regarding the content of the nine major oxides (in wt \%) and 31 trace elements (in $\mathrm{mg} / \mathrm{kg}$ ) as determined by ENAA and PGAA can be freely accessed at http:/ / dx.doi.org/ 10.17632/d5f8c9gtv7.2 [20], while the main statistical descriptors inclusive the experimental uncertainty defined as the combination of statistical and certified material uncertainties are provided in Table A1.

\section{Discussion}

Previous analysis of this core demonstrated that, by assuming a constant depositional rate, the maximum age of the sediments is about $1 \pm 0.1 \mathrm{ky}$ [18]. Given the quasi-regularity of lamina thickness (Figure 1), we have used the ${ }^{210} \mathrm{~Pb}$ data for determination of an estimated age to different sections of the core. At the same time, the core digital radiography has revealed the presence of about 254 laminae of which width varied between 1 and $3 \mathrm{~mm}$ (Figure 1), so we have attributed the core sediments to the Stratigraphic Unit 1 [29]—-the coccoliths mud [28,29].

The carbonate-rich coccolithic mud is well evidenced by the spider diagram (Figure 2a) which illustrates the distribution of eight major elements normalized to UCC [30] as well as on the $\mathrm{SiO}_{2}-$ $\mathrm{Al}_{2} \mathrm{O}_{3}-\mathrm{Na}_{2} \mathrm{O}+\mathrm{K}_{2} \mathrm{O}+\mathrm{CaO}$ ternary diagram shown in Figure $2 \mathrm{~b}$.
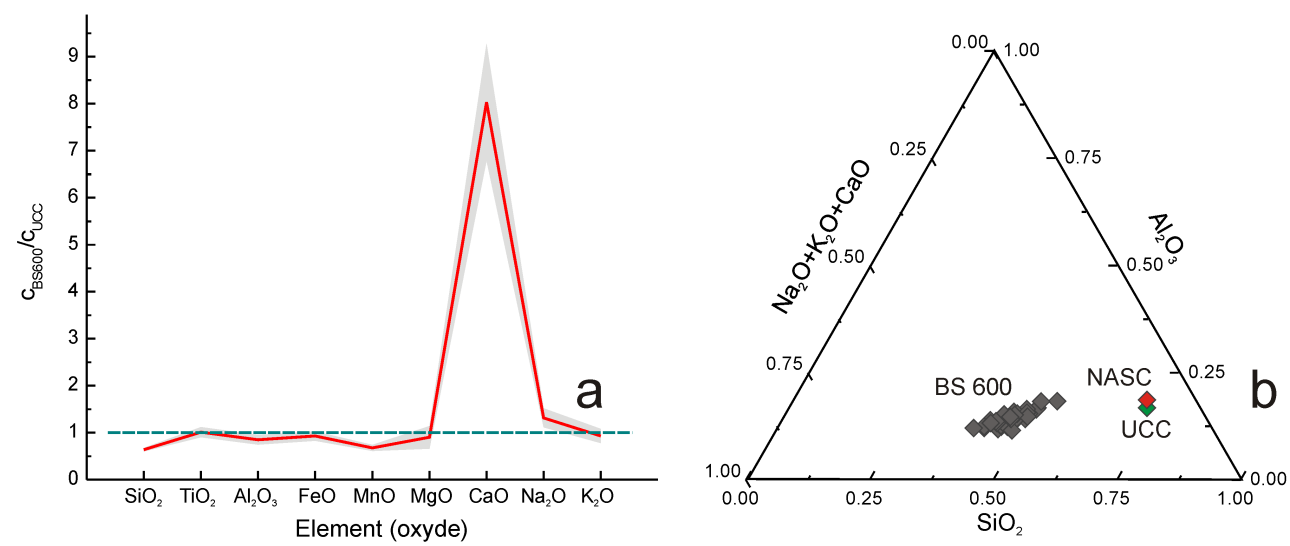

Figure 2. Spider diagram illustrating the distribution of the major elements (as oxides) normalized to Upper Continental Crust (UCC) (a) as well as a $\mathrm{SiO}_{2}-\mathrm{Al}_{2} \mathrm{O}_{3}-\mathrm{Na}_{2} \mathrm{O}+\mathrm{K}_{2} \mathrm{O}+\mathrm{CaO}$ ternary diagram (b) illustrating the relationship between the BS 600 major elements and the corresponding UCC and North American Shale Composite (NASC) ones.

According to the spider diagram, with the exception of $\mathrm{CaO}$, the content of all other major oxides remained relatively closer to the UCC (Figure 2a). This observation suggests that the BS600 sedimentary material is closer to the UCC with the exception of $\mathrm{CaO}$, which appears $7.9 \pm 1.2$ times higher then the UCC one (Table A2). In our opinion, the increased content of $\mathrm{CaO}$ reflects a carbonate accumulation, most probaby due to the presence of Emiliania huxleyi coccoliths [29,31] (Table A1).

This peculiarity is also evidenced on the ternary diagram illustrated in Figure 2b. Indeed, on this diagram, all $\mathrm{BS} 600$ sediments are shifted towards $\mathrm{SiO}_{2}$ smaller values with respect to UCC [30] and NASC [32] points. All of them form an elongated ellipse, so that the higher the $\mathrm{CaO}$ content, the more distant with respect to UCC and NASC they appear on the diagram. 
In this regard, it should be noted that the iron content as $\mathrm{FeO}$, if normalized to the sum of all other oxides except $\mathrm{CaO}$, gives a value of $0.067 \pm 0.007$, higher than the corresponding UCC value of 0.052. This suggests a moderately enriched content of iron in BS600 sediments in good agreement with literature data for the euxinic basin margin [10] but lower than those recorded for the deep euxinic basin [33].

Concerning the interrelation between the oxides of major components and $\mathrm{Cl}$, the correlation analysis shows the existence of at least two clusters (Table 1). One of them, which consists of $\mathrm{Na}, \mathrm{K}$, and $\mathrm{Cl}$, is most probably associated with of interstitial sea water. The content decreases towards core bottom by sediments compaction, a hypothesis sustained by the almost coincident vertical profile of $\mathrm{Na}_{2} \mathrm{O}$ and $\mathrm{Cl}$ (Figure A1). The second cluster contains $\mathrm{Al}, \mathrm{Si}$, Ti, and $\mathrm{Fe}$, presumably connected with the clay. At the same time, the calcium oxide negatively correlates with almost all other oxides as well as $\mathrm{Cl}$, peculiarly consistent with the $\mathrm{CaCO}_{3}$ distribution and totally complementary to the clay, as mentioned before.

Table 1. The matrix of Spearman's correlation coefficients between the oxides of major elements and $\mathrm{Cl}$ : The correlation significant at $p<0.05$ are represented in red and green.

\begin{tabular}{cccccccccc}
\hline & $\mathbf{S i O}_{2}$ & $\mathrm{TiO}_{2}$ & $\mathrm{Al}_{\mathbf{2}} \mathbf{O}_{\mathbf{3}}$ & $\mathbf{F e O}$ & $\mathbf{M n O}$ & $\mathbf{M g O}$ & $\mathbf{C a O}$ & $\mathbf{N a}_{\mathbf{2}} \mathbf{O}$ & $\mathbf{K}_{\mathbf{2}} \mathbf{O}$ \\
\hline $\mathrm{TiO}_{2}$ & 0.816 & & & & & & & & \\
$\mathrm{Al}_{2} \mathrm{O}_{3}$ & 0.429 & 0.346 & & & & & & & \\
$\mathrm{FeO}$ & 0.572 & 0.503 & 0.799 & & & & & & \\
$\mathrm{MnO}$ & -0.133 & -0.093 & 0.555 & 0.378 & & & & & \\
$\mathrm{MgO}$ & -0.142 & -0.093 & -0.368 & -0.264 & -0.231 & & & & \\
$\mathrm{CaO}$ & -0.839 & -0.638 & -0.636 & -0.783 & -0.027 & -0.045 & & & \\
$\mathrm{Na}{ }_{2} \mathrm{O}$ & 0.212 & 0.167 & 0.125 & 0.206 & -0.283 & 0.022 & -0.429 & & \\
$\mathrm{~K}_{2} \mathrm{O}$ & 0.520 & 0.363 & 0.311 & 0.511 & -0.078 & -0.046 & -0.704 & 0.564 & \\
$\mathrm{Cl}$ & 0.211 & 0.149 & -0.026 & 0.186 & -0.149 & 0.036 & -0.438 & 0.889 & 0.432 \\
\hline
\end{tabular}

Therefore, the BS 600 sediments appear, from the perspective of rock-forming elements, close to UCC and NASC. This peculiarity points out a predominance of terrigenous materials with a significant proportion of Emiliania huxleyi calcium carbonate [29]. At the same time, the moderately elevated Fe content could be attributed to the euxinic environment under which the sediments were deposited [10,33].

According to References [34,35], the particulate Fe oxides that exist in the upper, shallow oxic layer of the Black Sea when entering into anoxyc/euxinic water column are dissolved as Fe(III) is reduced to soluble Fe(II) and when reacting with dissolved hydrogen sulphide is deposited into sediments [10], where its content exceeds the content of the original sedimentary material.

For a better understanding of the behaviour of redox-sensitive elements under the Black Sea euxinic environment, in Figure 2, we have reproduced the vertical profile of the corresponding authigenic enrichment factors $(E F)$ [33] defined as

$$
E F=\left[\frac{c_{x}}{c_{A l}}\right]_{B S 600} /\left[\frac{c_{x}}{c_{A l}}\right]_{U C C}
$$

where the first term of the equation represents the ratio of the contents of considered element $x$ to $\mathrm{Al}$, as a descriptor of the detritial component of the sediments [28], while the second term is assigned to the ratio of the same elements in a reference material, in our case, the UCC. $x$ stands for Se, Mo, U, and Fe.

We have considered the UCC as a reference material by taking into account the previous results concerning the content of the nine major elements which indicate, for the BS600 sediments, a significant resemblance to both UCC and NASC average detritial materials.

Based on the experimental data [20], we have determined $E F$ values that varied between 2.4 and 170 in the case of Se, Mo, and $\mathrm{U}$ and between 0.75 and 1.36 with an average value $1.19 \pm 0.13$ in the case of Fe (Table 2). By comparing our data with the literature ones $[10,12,33]$, we noticed that, in the present case, the enrichment factors, except for in Reference [12], were slightly smaller. 
Table 2. The numerical values of the enrichment factor $(E F)$ of the investigated redox-sensitive elements in BS600 sediments and literature data.

\begin{tabular}{|c|c|c|c|c|c|c|c|}
\hline Element & $F F$ & Literature Data & & Element & $F F$ & Literature Data & \\
\hline \multirow[t]{3}{*}{$\mathrm{Fe}$} & $0.75-1.36$ & $\begin{array}{c}0.93-1.28 \\
\text { euxinic margin }\end{array}$ & [10] & Mo & $28-60$ & $\begin{array}{c}\text { 80-376 } \\
\text { euxinic stations } 9 \text { and14 }\end{array}$ & [33] \\
\hline & & $\begin{array}{l}1.84-2.78 \\
\text { euxinic basin }\end{array}$ & & & & & \\
\hline & & $\begin{array}{c}1.2-1.7 \\
\text { euxinic stations } 9 \text { and } 14\end{array}$ & [33] & & & & \\
\hline Se & $12-170$ & $\begin{array}{c}<59 \\
\text { clayed ooze }\end{array}$ & [12] & $\mathrm{U}$ & $2.4-6.1$ & $\begin{array}{c}1.5 \\
\text { clayed ooze }\end{array}$ & [12] \\
\hline
\end{tabular}

We explained this finding by the position of the BS600 collecting point on the slope of the continental platform, while the literature data $[10,12,33]$ refer to the Black Sea abyssal plain where the euxinic water column is significantly thicker.

This assumption is sustained in the case of Fe of which the content (Table A1) as well as EF are comparable with similar values provided in Reference [10] for the euxinic margin but smaller than those reported for the euxinic basin [33]. In the last case, all samples were collected in two deep stations located in the central part of the Black Sea where the euxinic water column reaches maximum values. In a similar situation, we have found in the case of Mo, of which $E F$ reached a maximum value of 60, a smaller value than the minimum value of 80 reported in Reference [33].

This situation could also contribute the finely suspended sedimentary material transported by the Danube river that could reach the BS600 sampling point situated on the slope of the continental platform at about $200 \mathrm{~km}$ from the Daube Delta (Figure 1-inset).

Another peculiarity observed for the $E F$ vertical profiles (Figure 3 ) is the significant fluctuation at depths varying between 15 to $25-30 \mathrm{~cm}$, the same depths where the clay and carbonate contents reached the maximum variability (Figure 1b). By assuming for the entire column an age of about $1 \mathrm{ky}$ [18], this sector could have an age between 300 and $600 \mathrm{y} \mathrm{BP}$, which partially coincides with the Little Ice Age. Another possible explanation could be linked with the onset of the Industrial Revolution and its significant environmental impact.

A similar peculiarity was evidenced by investigating the vertical distribution of the La/Th ratio. Usually, its value varies between 2.85 for loess [36] and 2.97 for UCC [30]. In our case, we have noticed an average value of $2.95 \pm 0.29$, consistent with UCC. After a careful examination of its vertical distribution along the sediment column, we noticed that this ratio is almost constant between 20 and $50 \mathrm{~cm}$ and equal $2.8 \pm 0.14$ but increases to the surface of sediments to almost 3.5 (Figure A3a). We have noticed an analogous behaviour for the $\mathrm{La} / \mathrm{Yb}$ ratio. Although the average value of the $\mathrm{La} / \mathrm{Yb}$ ratio was of $13.4 \pm 2.1$, very close to 13.6, which is characteristic for the UCC [36], the La/Yb vertical profile showed increasing values towards the sediment surface (Figure A3b) mainly due to a sizeable enlargement of the La content while $\mathrm{Yb}$ and Th content remained almost constant along the entire core [20].

Both cases showed a remarkable resemblance to the vertical profiles of anthropogenic $\mathrm{Zn}$, As, $\mathrm{Br}, \mathrm{Sn}$, and $\mathrm{Sb}$ reported earlier for the same sediments [37] and attributed to the 18th to 20th century industrial development of the Western European countries accompanied by massive deforestation. At the same time, factories and power plants frequently located near water bodies disposed large amounts of industrial waste, which were transported by tributary rivers and especially by Danube, and have contaminated the superficial layers of the Black Sea sediments.

While the EF vertical profiles of Fe, Mo, and $U$ fluctuated at about the same value, the Se EF presents a well-defined tendency to increase with the depth (Figure 3b).

Selenium belongs to the 16th group of the periodic table. In sea water and under oxic conditions, Se is soluble as selenate $\mathrm{SeO}_{4}^{2-}$ or selenite $\mathrm{SeO}_{3}^{2-}$ ions [38]. In a more reducing environment such 
as an euxinic one, Se occurs as insoluble selenide $\mathrm{Se}^{2-}$ ion or even as metallic Se, which are further incorporated into sediments [39]. Moreover, the presence of insoluble Se is related to the activity of both aerobic and anaerobic organisms. Therefore, the presence of the euxinic environment together with the activity of anaerobic bacteria could explain the increased content of Se in BS600 sediments as well as its characteristic vertical profile (Figure 3b).
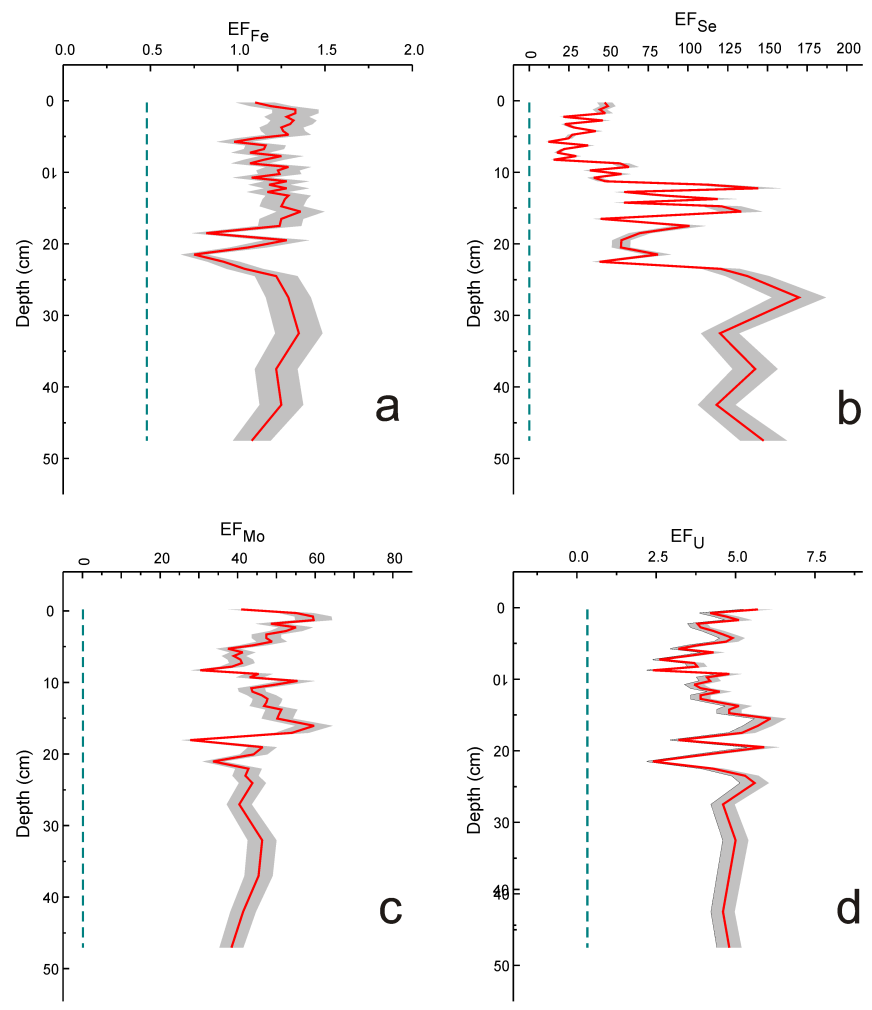

Figure 3. The vertical distribution of the EF of Fe (a), Se (b), Mo (c), and U (d): The vertical dashed lines correspond to the UCC enrichment factor.

A further Principal Component Analysis (PCA) performed on all trace elements within all 45 sections suggested the presence of two clusters. The first cluster consists of the sediments up to a depth of $20 \mathrm{~cm}$, and the other one comprises the rest of sediments until the core bottom (Figure A1).

The loading factors of the Principal Components (PCs) PC1 and PC2 are reproduced in Table A3 (Appendix A). In the case of $\mathrm{PC} 1$ which assures $38.5 \%$ of total variability, the main contributors are $\mathrm{Na}_{2} \mathrm{O}, \mathrm{Cl}$, and $\mathrm{K}_{2} \mathrm{O}$, i.e., elements associated with the marine environment and which, as mentioned before, form a cluster (Table 1). The PC1 contains also the possible anthropogenic contaminants $\mathrm{Zn}$, $\mathrm{As}, \mathrm{Br}, \mathrm{Sn}$, and $\mathrm{Sb}$ as well La, i.e., those element of which content significantly increased toward sediment surface [37] (Figure A3). It should be remarked that the reduced contribution to PC1 of $\mathrm{SiO}_{2}, \mathrm{TiO}-2, \mathrm{Al}-2 \mathrm{O}-3, \mathrm{FeO}$, and $\mathrm{MgO}$, i.e., the major of components of sedimentary material of which presence could be attributed to argillaceous fraction, suggests the relative uniformity of the mineralogical composition of BS600 sedimentary material.

In the case of $\mathrm{PC} 2$, the main contribution comes from $\mathrm{CaO}$ and $\mathrm{Sr}$, two components mainly associated with the carbonate fraction of sediments.

The contents of relative immobile elements such as $\mathrm{Ti}$, a ubiquitous component of the terrestrial rocks and $\mathrm{Ni}$, could be used to differentiate immature sedimentary material resulting from magmatic precursors from the mature sedimentary ones [16]. Correlated with a ternary discriminating diagram Sc-La-Th [36], this type of graphic analysis was useful in confirming the terrigenous origin of BS600 sedimentary material. Indeed, both Figure $4 \mathrm{a}, \mathrm{b}$ point towards a significant resemblance of the BS600 material with the UCC and NASC. 

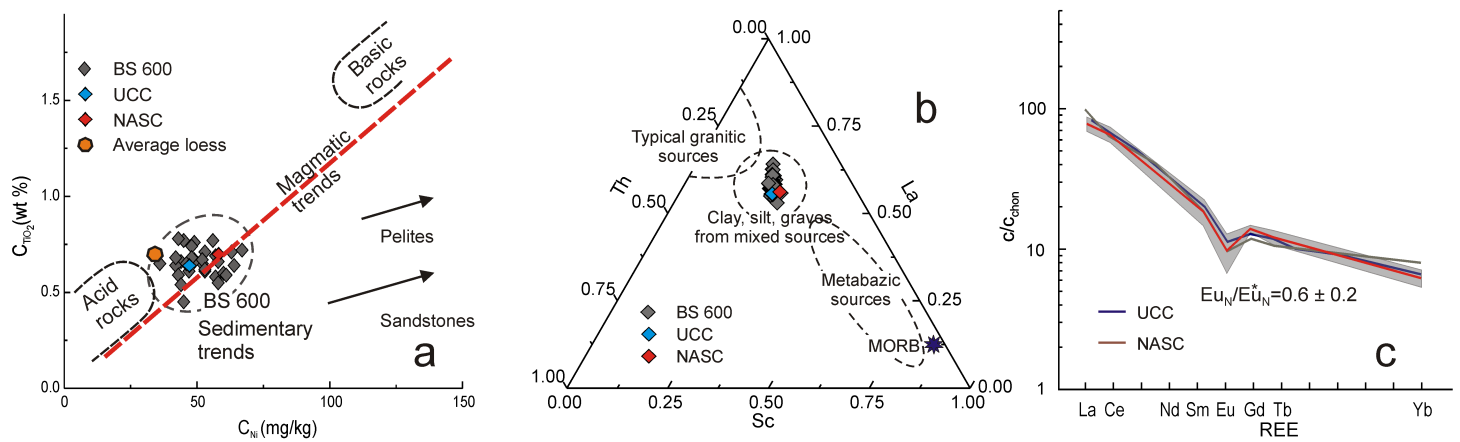

Figure 4. A $\mathrm{TiO}_{2}$ vs Ni diagram [16] (a), a discriminating ternary Sc-La-La (b) [15], as well as a chondrite normalization REE plot (c) proving the similarity between the BS600 sediments and UCC [30] and NASC [32], suggesting a continental, terrigenous origin of the BS600 sediments.

This finding could be confirmed by the distribution of eight REE as determined by ENAA (La, Ce, $\mathrm{Nd}, \mathrm{Sm}, \mathrm{Eu}, \mathrm{Tb}$, and $\mathrm{Yb}$ ) and PGAA (Gd) and normalized to chondrite [40] (Figure 4c). This diagram evidences no negative Ce anomaly as would be expected in the case of euxinic/reducing conditions but a well-represented negative Eu anomaly [15] described by an average value of $\mathrm{Eu}_{N} / \mathrm{Eu}_{N *}$ of $0.6 \pm 0.2$, close to 0.67 for UCC [30].

The absence of a Ce negative anomaly could be related to the relative reduced depth of the anoxic/euxinic water column of only $450 \mathrm{~m}$ as well as to the vicinity of Danube Delta through which the majority of fresh sedimentary material is discharged into Black Sea. In the absence of more literature data on Ce anomalies, further research concerning different region of the Black Sea would be necessary.

While Ce anomaly is determined by the oxic-anoxic condition of a depositional environment, an Eu negative anomaly is a characteristic for UCC [30] as well as recycled sedimentary rocks [15] such as NASC [32] or PAAS [36]. This fact confirms once more the contribution of terrigenous continental material to BS600 sediments.

Zircon, the natural silicate of zirconium shows a remarkable resilience to abrasion. For this reason, $\mathrm{Zr}$ content by means of a Th/Sc vs. $\mathrm{Zr} / \mathrm{Sc}$ biplot could be used in establishing to which extent the sedimentary material was recycled [41]. In the case of BS600 material, all samples showed a relatively reduced content of $\mathrm{Zr}$ (Figure 5), all of them being grouped around the UCC and NASC locations, different from the Dobrogea (Romania) loess [42], in good agreement with Reference [4], which indicates also a negligible fraction of loess in the BS600 core sedimentary material.

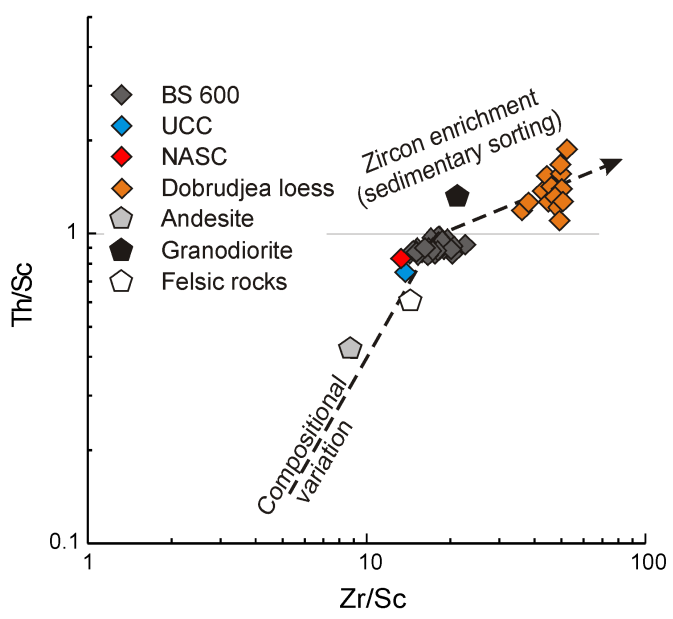

Figure 5. A discriminating biplot of Th/Sc vs. Zr/Sc illustrates the absence of Zr enrichment of BS600 sediments due to weak recycling, suggesting the presence of a relative fresh sedimentary material [41]. 


\section{Conclusions}

The vertical profiles of nine major elements as well as 33 trace elements were investigated in a 50-cm core collected from the euxinic zone of the Western Black Sea by means of instrumental neutron activation analysis. Previous ${ }^{137} \mathrm{Cs}$ and ${ }^{210} \mathrm{~Pb}$ geochronologies documented an age of about 1000 years for the oldest sediments. As the core was sliced in 45 segments of which thickness varied between 0.5 and $5 \mathrm{~cm}$, it was possible to reconstruct the depositional environment with a resolution of 10 and 100 years.

Our study evidenced a complex sedimentary pattern consisting of both terrigenous material close to the upper continental crust and coccolithic calcium carbonate, all coexisting in a relatively stationary euxinic condition as the vertical profile of redox-sensitive elements $\mathrm{Fe}$, Se, Mo, and U confirm. Their vertical profile suggests changes of the sediments geochemistry for the past four centuries, most probably associated with the end of the Little Ice Age and the Industrial Revolution in Western Europe.

A chondrite-normalized plot of eight REE displayed a Eu negative anomaly, in good concordance with the continental origin of sedimentary material.

Author Contributions: Conceptualization, G.O. and O.G.D.; methodology, G.O., O.G.D., C.I.C., O.-A.C., and M.V.F.; statistic analysis, O.G.D.; validation, A.-V.B. and E.C.; writing and editing, O.G.D.

Funding: This research received no external funding.

Acknowledgments: The work was partially realized within cooperation protocols no. 4322-4-14/16 and 4322-4$17 / 19$ between the University of Bucharest and the Joint Institute for Nuclear Research, Dubna, Russian Federation represented by the Frank Neutron Physics Laboratory. We are much indebted to Dan Secrieru from the National Institute of Marine Geology and Geoecology for his useful comments concerning sediment geochemistry and to Mariana Marinescu for her help in editing the manuscript. Many thanks to Jasmina Obhodas for her interest and support in presenting these data.The work is dedicated to the memory of Gigi Oaie, the former director of the National Institute for Marine Geology and Geoecology, Bucharest, Romania who passed away during the preparation of this manuscript. We are also grateful to the three anonymous reviewers for their useful remarks and suggestions

Conflicts of Interest: The authors declare no conflict of interest.

\section{Abbreviations}

The following abbreviations are used in this manuscript:

EF Enrichment Factor

ENAA Epithermal Neutron Activation Analysis

INAA Instrumental Neutron Activation Analysis

NASC North American Shale Composite

PAAS Post-archaean Australian Average Shale

PC Principal Component

PCA Principal Component Analysis

PGAA Prompt Gamma-ray Activation Analysis

UCC Upper Continental Crust

XRD X-ray Diffraction 


\section{Appendix A}

Table A1. The average values $(c)$, standard deviations $(\sigma)$, and combined standard uncertainty $\left(u_{c}\right)$ of BS600 elements together with the corresponding contents of UCC and NASC: Oxide contents are expressed in wt \%, and the content of the other elements are expressed in $\mathrm{mg} / \mathrm{kg}$. $n$-no data. Total experimental uncertainty is defined as the combination of statistical and certified material uncertainties.

\begin{tabular}{cccccccccccc}
\hline Element & $\boldsymbol{c}$ & $\boldsymbol{\sigma}$ & $\boldsymbol{u}_{\boldsymbol{c}}$ & UCC & NASC & Element & $\boldsymbol{c}$ & $\boldsymbol{\sigma}$ & $\boldsymbol{u}_{\boldsymbol{c}}$ & UCC & NASC \\
\hline $\mathrm{SiO}_{2}$ & 42.07 & 2.56 & $3.0 \%$ & 66.62 & 64.8 & $\mathrm{Zr}$ & 189 & 27 & $3.8 \%$ & 193 & 200 \\
$\mathrm{TiO}_{2}$ & 0.64 & 0.07 & $6.2 \%$ & 0.64 & 0.7 & $\mathrm{Mo}$ & 42.5 & 5 & $3.3 \%$ & 1.1 & $n$ \\
$\mathrm{Al}_{2} \mathrm{O}_{3}$ & 12.87 & 1.56 & $2.5 \%$ & 15.4 & 16.9 & $\mathrm{Sn}$ & 2.9 & 1.4 & $6.7 \%$ & 2.1 & $n$ \\
$\mathrm{FeO}$ & 5.11 & 0.5 & $3.8 \%$ & 5.04 & 5.66 & $\mathrm{Sb}$ & 2.7 & 1.4 & $8.7 \%$ & 0.4 & $n$ \\
$\mathrm{MnO}$ & 0.07 & 0.01 & $4.9 \%$ & 0.1 & 0.06 & $\mathrm{I}$ & 94 & 24 & $8.5 \%$ & 1.4 & $n$ \\
$\mathrm{MgO}$ & 2.2 & 0.59 & $5.2 \%$ & 2.48 & 2.86 & $\mathrm{Cs}$ & 5.5 & 0.7 & $6.3 \%$ & 4.9 & $n$ \\
$\mathrm{CaO}$ & 28.41 & 4.41 & $7.0 \%$ & 3.59 & 3.63 & $\mathrm{Ba}$ & 488 & 127 & $8.8 \%$ & 624 & 636 \\
$\mathrm{Na} \mathrm{O}_{2} \mathrm{O}$ & 4.24 & 0.66 & $7.5 \%$ & 3.27 & 1.14 & $\mathrm{La}$ & 29 & 4 & $8.5 \%$ & 31 & 31 \\
$\mathrm{~K} 2$ & 2.56 & 0.42 & $4.5 \%$ & 2.8 & 3.97 & $\mathrm{Ce}$ & 63 & 8 & $8.3 \%$ & 63 & 67 \\
$\mathrm{Cl}$ & 4030 & 620 & $3.5 \%$ & 370 & $n$ & $\mathrm{Nd}$ & 22.7 & 6.6 & $7.5 \%$ & 27 & 27 \\
$\mathrm{Sc}$ & 11 & 1.2 & $6.9 \%$ & 14 & 15 & $\mathrm{Sm}$ & 3.8 & 0.95 & $5.8 \%$ & 4.7 & 5.6 \\
$\mathrm{~V}$ & 110 & 19 & $8.8 \%$ & 97 & 130 & $\mathrm{Eu}$ & 0.8 & 0.3 & $8.8 \%$ & 1 & 1.2 \\
$\mathrm{Cr}$ & 62 & 11.2 & $7.7 \%$ & 92 & 125 & $\mathrm{Gd}$ & 4.1 & 0.8 & $8.9 \%$ & 4 & 5.2 \\
$\mathrm{Co}$ & 16 & 2 & $6.8 \%$ & 17.3 & 26 & $\mathrm{~Tb}$ & 0.7 & 0.1 & $8.3 \%$ & 0.7 & 0.05 \\
$\mathrm{Ni}$ & 53 & 8 & $8.9 \%$ & 47 & 58 & $\mathrm{Yb}$ & 1.8 & 0.2 & $8.2 \%$ & 2 & 3.1 \\
$\mathrm{Zn}$ & 82 & 19 & $5.5 \%$ & 67 & $n$ & $\mathrm{Hf}$ & 5.1 & 0.6 & $8.5 \%$ & 5.3 & 6.3 \\
$\mathrm{As}$ & 11.1 & 2 & $7.9 \%$ & 4.8 & $n$ & $\mathrm{Ta}$ & 0.7 & 0.1 & $7.6 \%$ & 0.9 & 1.1 \\
$\mathrm{Se}$ & 5.2 & 3.3 & $6.9 \%$ & 0.09 & $n$ & $\mathrm{~W}$ & 5 & 3.1 & $7.3 \%$ & 1.9 & $n$ \\
$\mathrm{Br}$ & 87 & 20.8 & $8.9 \%$ & 1.6 & $n$ & $\mathrm{Th}$ & 9.8 & 1.2 & $7.1 \%$ & 10.5 & 12.5 \\
$\mathrm{Rb}$ & 84 & 11.1 & $8.2 \%$ & 84 & 125 & $\mathrm{U}$ & 9.9 & 1.2 & $8.3 \%$ & 2.7 & 2.7 \\
$\mathrm{Sr}$ & 710 & 180 & $5.5 \%$ & 320 & 142 & & & & & & \\
\hline
\end{tabular}

Table A2. The vertical distribution of the content (in \%) of main mineral components of the BS600 sediments: Carb—carbonate, Qtz-quartz, Gl—glauconite, and Gyp—gypsum. (G. Caraivan, unpublished results).

\begin{tabular}{cccccccccccc}
\hline Depth $(\mathbf{m m})$ & Clay & Carb & Qtz & Gl & Gyp & Depth $(\mathbf{m m})$ & Clay & Carb & Qtz & Gl & Gyp \\
\hline $0-5$ & 34 & 65 & - & - & - & $115-120 *$ & 35 & 60 & 3 & - & 1 \\
$5-10$ & 49 & 50 & 1 & - & - & $120-125$ & 44 & 55 & 1 & - & - \\
$10-15$ & 43 & 55 & 1 & - & 1 & $125-130$ & 60 & 40 & $<1$ & - & - \\
$15-20$ & 39 & 90 & 1 & - & - & $130-135 *$ & 35 & 60 & $<5$ & - & - \\
$20-25$ & 50 & 50 & - & - & - & $135-140$ & 50 & $\sim 50$ & $<1$ & - & - \\
$25-30$ & 35 & 65 & - & - & - & $140-145$ & 40 & 55 & 4 & - & 1 \\
$30-35$ & 56 & 40 & $<4$ & - & - & $145-150 *$ & 47 & 50 & 1 & - & 1 \\
$35-40$ & 48 & 50 & 2 & - & - & $150-160$ & 38 & 60 & $\sim 2$ & - & - \\
$40-45$ & 32 & 60 & 8 & - & - & $160-170$ & 48 & 50 & 1 & - & $\sim 1$ \\
$45-50$ & 58 & 40 & 1 & - & $<1$ & $170-180$ & 47 & 50 & 2 & - & $<1$ \\
$50-55$ & 58 & 40 & 1 & - & $<1$ & $180-190$ & 45 & $\sim 50$ & $<5$ & $<1$ & - \\
$55-60$ & 58 & 40 & 1 & 1 & - & $190-200$ & 35 & $\sim 60$ & $<5$ & $<1$ & - \\
$60-65$ & 25 & 70 & 4 & 0.5 & 0.5 & $200-210$ & 49 & $\sim 50$ & $<1$ & - & - \\
$65-70$ & 48 & 50 & 2 & - & - & $210-220$ & 49 & $\sim 50$ & $<1$ & - & - \\
$70-75$ & 45 & $\sim 55$ & $<0.5$ & - & - & $220-230$ & 60 & $\sim 40$ & $<0.5$ & - & - \\
$75-80$ & 17 & 80 & 2 & - & $<0.5$ & $230-240$ & 70 & $\sim 30$ & $<1$ & - & - \\
$80-85$ & 23 & 75 & $<1$ & - & 1 & $240-250$ & 60 & $\sim 40$ & $<1$ & - & - \\
$85-90$ & 23 & 75 & 0.5 & - & 1.5 & $250-300$ & 20 & 75 & 5 & - & - \\
$90-95$ & 16 & 80 & 3 & & $<1$ & $300-350$ & 50 & $\sim 50$ & $<1$ & - & - \\
$95-100$ & 8 & 90 & 1 & 1 & - & $350-400$ & $\sim 60$ & $\sim 40$ & - & - & - \\
$100-105$ & 45 & 90 & 1 & - & - & $400-450$ & 53 & 45 & 2 & - & - \\
$105-110$ & 30 & 70 & $<0.5$ & - & - & $450-500$ & 54 & 45 & 1 & - & - \\
$110-115$ & 35 & 63 & $\sim 1$ & - & 1 & - & - & - & - & - & - \\
\hline & & & & $* 0.5-\sim 1 \%$ microorganisms tests. & & & &
\end{tabular}




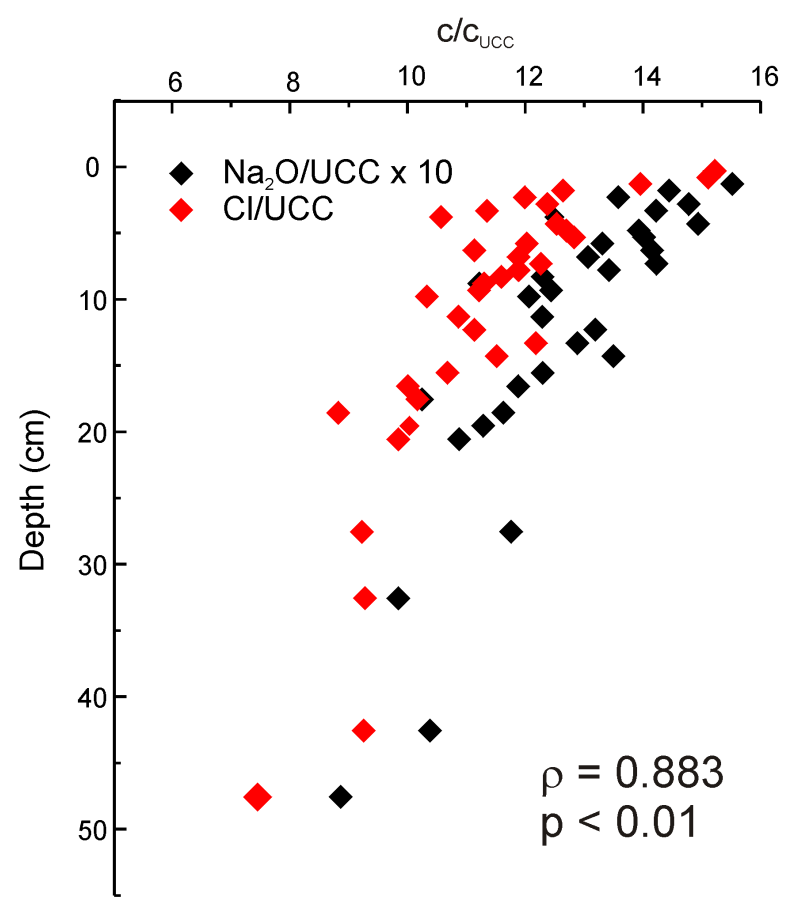

Figure A1. The vertical profile of $\mathrm{Na}_{2} \mathrm{O}$ and $\mathrm{Cl}$ in the $\mathrm{BS} 600$ sediments: Both contents were normalized to the UCC [30]. For a better illustration, the $\mathrm{Na}_{2} \mathrm{O}$ content normalized to UCC [30] was represented multiplied by 10 . It should be remarked that both contents decrease synchronically with the sediment depth.

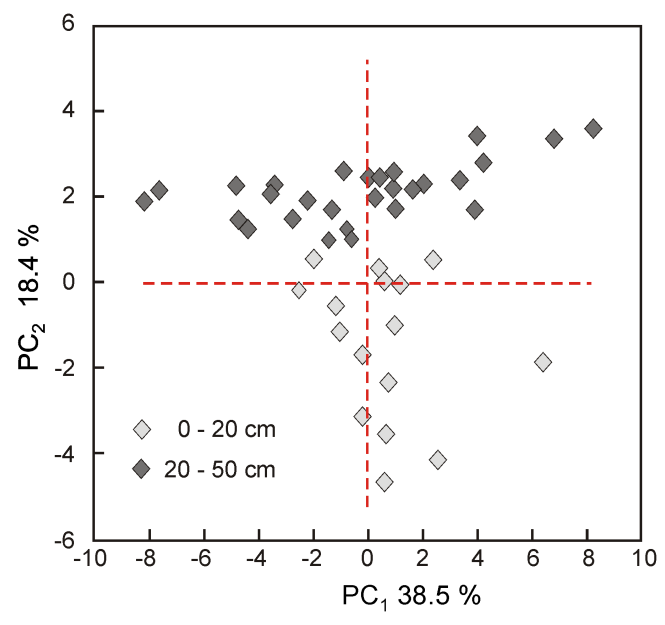

Figure A2. The result of the Principal Component Analysis (Q mode) suggesting the existence of two clusters: one consisting of sediments covers the first $20 \mathrm{~cm}$ of the DS600 sedimentary column, and the other consists of the rest of the samples. It should be remarked that according to Reference [18] geochronology, the first $20 \mathrm{~cm}$ correspond to the last $400 \mathrm{y}$, the end of the Little Ice Age, and the beginning of the Industrial Revolution in Western and Central Europe. 
Table A3. The loading factors of the Principal Components (PCs) PC1 and PC2.

\begin{tabular}{ccccccccc}
\hline Element & PC1 & PC2 & Element & PC1 & PC2 & Element & PC1 & B \\
\hline $\mathrm{SiO}_{2}$ & 0.231 & -0.442 & $\mathrm{Ni}$ & 0.104 & 0.005 & $\mathrm{La}$ & 0.538 & -0.452 \\
$\mathrm{TiO}_{2}$ & 0.086 & -0.225 & $\mathrm{Zn}$ & 0.828 & 0.117 & $\mathrm{Ce}$ & -0.123 & -0.239 \\
$\mathrm{Al}_{2} \mathrm{O}_{3}$ & -0.118 & -0.589 & $\mathrm{As}$ & 0.706 & -0.214 & $\mathrm{Nd}$ & -0.383 & 0.243 \\
$\mathrm{FeO}$ & -0.017 & -0.505 & $\mathrm{Se}$ & -0.561 & 0.155 & $\mathrm{Sm}$ & 0.328 & -0.616 \\
$\mathrm{MnO}$ & -0.365 & -0.226 & $\mathrm{Br}$ & 0.579 & 0.022 & $\mathrm{Eu}$ & 0.461 & -0.315 \\
$\mathrm{MgO}$ & 0.040 & -0.006 & $\mathrm{Rb}$ & 0.059 & -0.391 & $\mathrm{Gd}$ & 0.074 & -0.474 \\
$\mathrm{CaO}$ & -0.275 & 0.551 & $\mathrm{Sr}$ & -0.448 & 0.881 & $\mathrm{~Tb}$ & 0.31 & -0.479 \\
$\mathrm{Na}_{2} \mathrm{O}$ & 0.924 & 0.048 & $\mathrm{Zr}$ & 0.207 & -0.040 & $\mathrm{Yb}$ & 0.087 & -0.140 \\
$\mathrm{~K}_{2} \mathrm{O}$ & 0.427 & -0.437 & $\mathrm{Mo}$ & 0.334 & -0.021 & $\mathrm{Hf}$ & 0.375 & -0.364 \\
$\mathrm{Cl}$ & 0.999 & 0.036 & $\mathrm{Sn}$ & 0.464 & 0.304 & $\mathrm{Ta}$ & 0.207 & -0.419 \\
$\mathrm{Sc}$ & 0.110 & -0.426 & $\mathrm{Sb}$ & 0.833 & 0.180 & $\mathrm{~W}$ & 0.369 & 0.140 \\
$\mathrm{~V}$ & 0.019 & -0.070 & $\mathrm{I}$ & 0.247 & 0.427 & $\mathrm{Th}$ & 0.046 & -0.282 \\
$\mathrm{Cr}$ & -0.321 & 0.186 & $\mathrm{Cs}$ & 0.075 & -0.563 & $\mathrm{U}$ & -0.27 & 0.511 \\
$\mathrm{Co}$ & 0.171 & -0.222 & $\mathrm{Ba}$ & 0.345 & 0.356 & & & \\
\hline
\end{tabular}
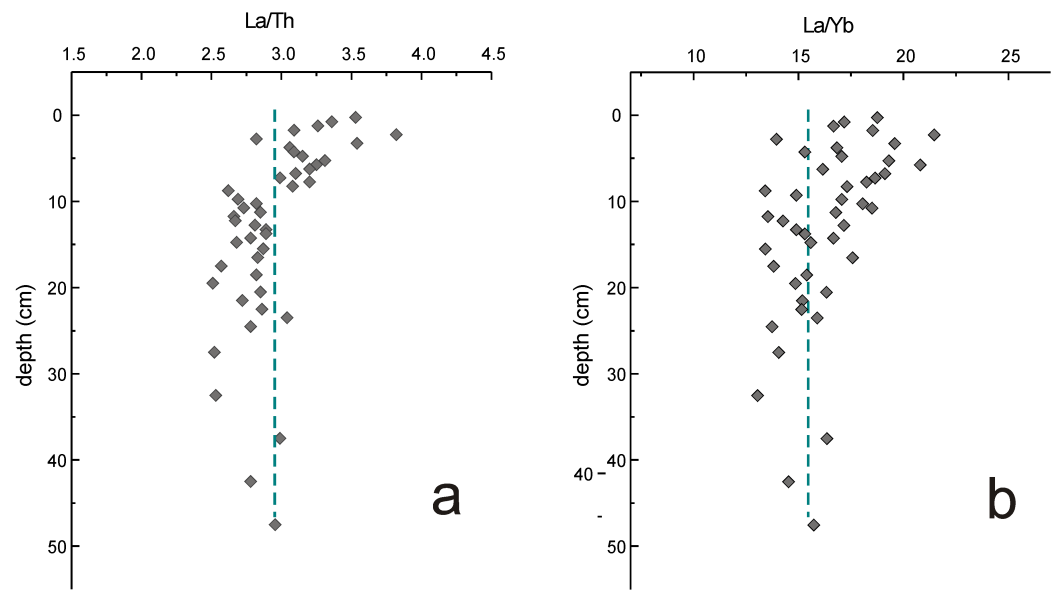

Figure A3. The vertical profiles of the $\mathrm{La} / \mathrm{Th}(\mathbf{a})$ and $\mathrm{LaYb}(\mathbf{b})$ ratios: The vertical green dotted line corresponds to 2.95 (a) and 15 (b) UCC [30] values of the La/Th and La/Y ratios.

\section{References}

1. European Comision. The Black Sea: Facts and Figures, Environment and Enlargement. Available online: http:/ / ec.europa.eu/environment/enlarg/blackseafactsfigures_en.htm (accessed on 18 August 2019).

2. Murray, J.W.; Jannasch, H.W.; Honjo, S.; Anderson, R.F.; Reeburgh, W.S.; Top, Z.; Friederich, G.E.; Codispoti, L.A.; Izdar, E. Unexpected changes in the oxic/anoxic interface in the Black Sea. Nature 1989, 338, 411-413. [CrossRef]

3. Özsoy, E.; Unluata, U. Oceanography of the Black Sea: A review of some recent results. Earth Sci. Rev. 1997, 42, 231-272. [CrossRef]

4. Vespremeanu, E.; Golumbeanu, M. Catchment Area of the Black Sea. In The Black Sea: Physical, Environmental and Historical Perspectives; Vespremeanu, E., Golumbeanu, M., Eds.; Springer Geography: Cham, Switzerland, 2018; pp. 15-25.

5. Panin, N.; Jipa, D.C.; Gomoiu, M.-T.; Secrieru, D. Importance of Sedimentary Processes in Environmental Changes: Lower River Danube-Danube Delta-Western Black Sea System. In Environmental Degradation of the Black Sea: Challenges and Remedies; Besiktepe, S.T., Ünlüata, Ü., Içel, E., Bologa, A.S., Eds.; Kluwer: Dordrecht, The Netherlands, 1999; pp. 23-41.

6. Panian, N.; Jipa, D. Danube River sediments input and interaction with the Northwest Black Sea. Estuar. Coast. Shelf Sci. 2002, 54, 551-562. [CrossRef] 
7. Crusius, J.; Calvert, S.; Pedersen, T.; Sage, D. Rhenium and molybdenum enrichments in sediments as indicators of oxic, suboxic and sulfidic conditions of deposition. Earth Planet. Sci. Lett. 1996, 145, 65-78. [CrossRef]

8. Crusius, J.; Thomson, J. Mobility of authigenic rhenium, silver, and selenium during postdepositional oxidation in marine sediments. Geochim. Cosmochim. Acta 2003, 67, 265-273. [CrossRef]

9. Morford, J.L.; Emerson, S. The geochemistry of redox sensitive trace metals in sediments. Geochim. Cosmochim. Acta 1999, 63, 1735-1750. [CrossRef]

10. Lyons, T.W.; Severmann, S. A critical look at iron paleoredox proxies: New insights from modern euxinic marine basins. Geochim. Cosmochim. Acta 2006, 70, 5698-5722. [CrossRef]

11. Boothman, W.S.; Coiro, L.L. Laboratory determination of molybdenum accumulation rates as a measure of hypoxic conditions. Estuaries Coasts 2009, 32, 642-653. [CrossRef]

12. Baturin, G.N. Geochemistry of Sapropel in the Black Sea. Geochem. Int. 2011, 49, 531-535. [CrossRef]

13. Eckert, S.; Brumsack, H.-J.; Severmann, S.; Schnetger, B.; März, C.; Frröllje, H. Establishment of euxinic conditions in the Holocene Black Sea. Geology 2013, 41, 431-434. [CrossRef]

14. Piper, D.Z. Rare earth elements in the sedimentary cycle: A summary. Chem. Geol. 1974 14, $285-304$. [CrossRef]

15. McLennan, S.M.; Hemming, S.; McDaniel, K.; Hanson, G.L. Geochemical Approaches to Sedimentation, Provenance, and Tectonics. In Processes Controlling the Composition of Clastic Sediments; Johnsson, M.J., Basu, A., Eds.; Geological Society of America Special Paper: Boulder, CO, USA, 1993; Volume 284, pp. 21-40.

16. Floyd, P.A.; Winchester, J.A.; Park, R.G. Geochemistry and tectonic setting of Lewisian clastic metasediments from the Early Proterozoic Loch Maree Group of Gairloch, NW Scotland. Precambrian Res. 1989, 45, $203-214$. [CrossRef]

17. Owens, P.N.; Blake, W.H.; Gaspar, L.; Gateuille, D. Fingerprinting and tracing the sources of soils and sediments: Earth and ocean science, geoarchaeological, forensic, and human health applications. Earth Sci. Rev. 2016, 162, 1-23. [CrossRef]

18. Florea, N.; Cristache, C.; Oaie, G.; Duliu, O.G. Concordant ${ }^{137} \mathrm{Cs}$ and ${ }^{210} \mathrm{~Pb}$ ages of Black Sea anoxic unconsolidated sediments. Geochronometria 2011, 38, 101-106. [CrossRef]

19. Oaie, G.; Florescu, S. Mare Nigrum-The First Romanian Multidisciplinary Research Vessel in Romania. GeoEcoMarina 2003-2004, 9-10. Available online: http:/ / www.geoecomar.ro/website/publicatii/Nr.9-102004/22.pdf (accessed on 16 May 2019).

20. Duliu, O.G. Major and Trace Elements in Black Sea Euxinic Sediments. Mendeley Data 2019, v1. Available online: http:/ / dx.doi.org/10.17632/d5f8c9gtv7.1 (accessed on 4 September 2019).

21. Hussein, E.M.A. Handbook on Radiation Probing, Gauging, Imaging and Analysis; Kluwer: New York, NY, USA, 2004.

22. Frontasyeva, M.V. Neutron activation analysis in the life sciences. Phys. Part. Nucl. 2011, 42, 332-378. [CrossRef]

23. Alfassi, B. Epithermal neutron activation analysis. J. Radioanal. Nucl. Chem. 1985, 90, 151-165. [CrossRef]

24. Molnár, G.L. (Ed.) Handbook of Prompt Gamma Activation Analysis with Neutron Beams; Springer, Kluwer Acadernic Publishers: Dordrecht, The Netherlands, 2004.

25. Cristache, C.; Gméling, K.; Culicov, O.; Frontasyeva, M.V.; Toma, M.; Duliu, O.G. An ENAA and PGAA comparative study of anoxic Black Sea sediments. J. Radioanal. Nucl. Chem. 2009, 279, 7-12. [CrossRef]

26. Zinicovscaia, I.; Duliu, O.G.; Culicov, O.-A.; Frontasyeva, M.V.; Sturza, R. Major and trace elements distribution in Moldavian soils. Rom. Rep. Phys. 2018, 70, 701.

27. Crystallography Open Database. 2019. Available online: http://www.crystallography.net/ (accessed on 1 February 2019).

28. Calvert, S.E.; Pedersen, T.F. Geochemistry of recent oxic and anoxic marine sediments: Implications for the geological record. Mar. Geol. 1993, 113, 67-88. [CrossRef]

29. Ross, D.A.; Degens, E.T. Recent Sediments of the Black Sea. In The Black Sea-Geology, Chemistry and Biology; Degens, E.T., Ross D.A., Eds.; American Association of Petroleum Geologists: Tulsa, OK, USA, 1974; Volume 20, pp. 183-199.

30. Rudnick, R.L.; Gao, S. Composition of the Continental Crust. In Treatise on Geochemistry; Holland, H.D., Turekian, K.K., Eds.; Elsevier-Pergamon: Oxford, UK; London, UK, 2003; Volume 3, pp. 1-64. 
31. Calvert, S.E.; Karlin, R.E. Organic carbon accumulation in the Holocene sapropel of the Black Sea. Geology 1988, 26, 107-110. [CrossRef]

32. Gromet, L.P.; Haskin, L.A.; Korotev, R.L.; Dymek, R.F. The "North American shale composite": Its compilation, major and trace element characteristics. Geochim. Cosmochim. Acta 1984, 48, 2469-2482. [CrossRef]

33. Little, S.H.; Vance, D.; Lyons, T.W.; McManus, J. Controls on trace metal authigenic enrichment in reducing sediments: Insights from modern oxygen-deficient settings. Am. J. Sci. 2015, 315, 77-119. [CrossRef]

34. Scholz, F.; Severmann, S.; McManus, J.; Hensen, C. Beyond the Black Sea paradigm: The sedimentary fingerprint of an open-marine iron shuttle. Geochim. Cosmochim. Acta 2014, 127, 368-380. [CrossRef]

35. Anderson, T.F.; Raiswell, R. Sources and mechanisms for the enrichment of highly reactive iron in euxinic Black Sea sediments. Am. J. Sci. 2004, 304, 203-233. [CrossRef]

36. Taylor. S.; McLennan, S.M. The Continental Crust: Its Composition and Evolution; Blackwell: Oxford, UK, 1991.

37. Duliu, O.G.; Cristache, C.; Oaie, G.; Culicov, O.A.; Frontasyeva, M.V.; Toma, M. ENAA Studies of pollution in anoxic Black Sea sediments. Mar. Pollut. Bull. 2009, 58, 827-831. [CrossRef]

38. McNeal, J.M.; Feder, G.L.; Wiber, W.G.; Deverel, S.J. Environmental concern related to selenium in western United States. In Proceedings of the a U.S. Geological Survey Workshop on Environmental Geochemistry; Doe, B.R., Ed.; USGS: Denver, CO, USA, 1990.

39. Velinsky, D.J.; Cutter, G.A. Geochemistry of selenium in a coastal salt marsh. Geochim. Cosmochim. Acta 1991, 55, 179-191. [CrossRef]

40. McDonough, W.F.; Sun, S.S. The Composition of the Earth. Chem. Geol. 1995, 120, 223-253. [CrossRef]

41. McLennan, S.M. Rare Earth Elements in Sedimentary Rocks: Influence of Provenance and Sedimentary Processes. In Review in Mineralogy, Lipin, B.R., McKay, G.A., Eds.; Mineralogical Society of America: Washington, DC, USA, 1989; Volume 21; pp. 147-167.

42. Tugulan, L.; Duliu, O.G.; Bojar, A.-V.; Dumitras, D.; Zinicovscaia, I.; Culicov, O.A.; Frontasyeva, M.V. On the geochemistry of the Late Quaternary loess deposits of Dobrogea (Romania). Quat. Int. 2016, 399, 100-110. [CrossRef]

(C) 2019 by the authors. Licensee MDPI, Basel, Switzerland. This article is an open access article distributed under the terms and conditions of the Creative Commons Attribution (CC BY) license (http://creativecommons.org/licenses/by/4.0/). 